\title{
ولايت النصكاح
}

دراست فقهيت مقارنت

د. ابتسام محمد أحمد الغامدي
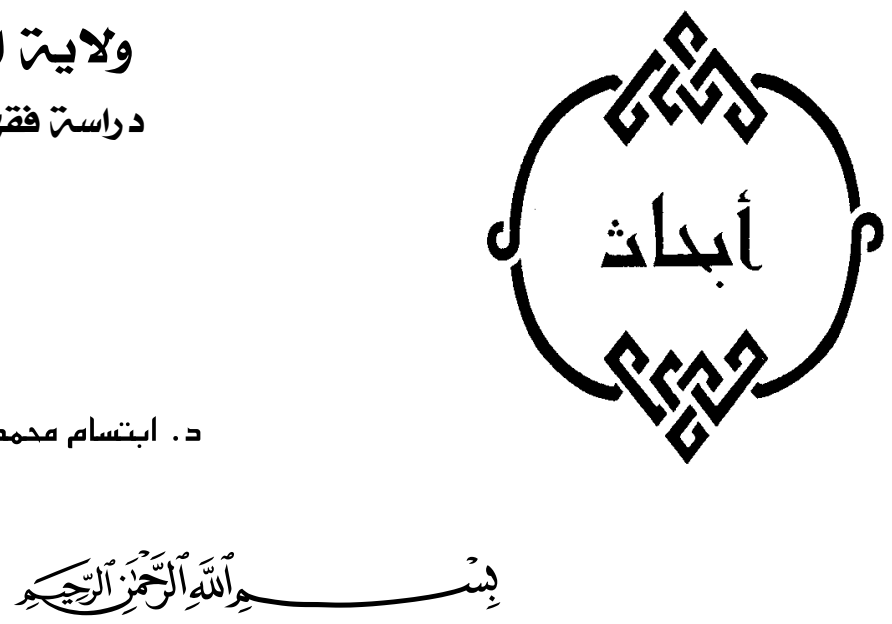

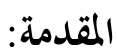

الحمد لله رب العالمين، حمدا كثيرا طيبا مبار كا فيه، والصالاة والسلام على خهـاتم

الأنبياء و المرسلين، نبينا محمد، وعلى آله وصحبه والتابعين، ومن تبعهم بإحســان إلى ريلى

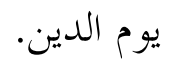

أما بعد:

فقد كرَّم الله المرأة بجعل الرجل هو من يقوم على أمرها ويحفظها، وأوصـى هــــا،

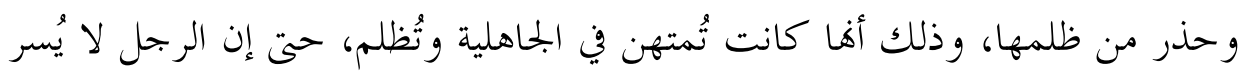

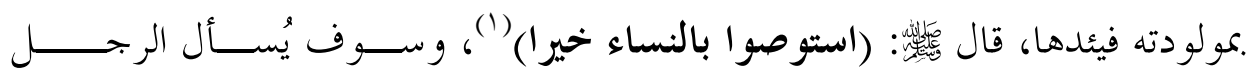

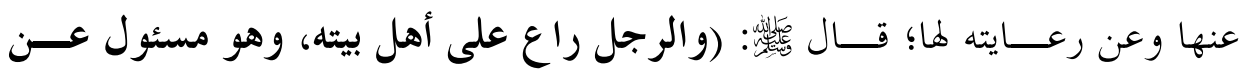

$$
\begin{aligned}
& \text { (1) (أستاذ مساعد بجامعة أم القرى - كلية الشريعة والدراسات الإسلامية - قسم الشريعة. }
\end{aligned}
$$

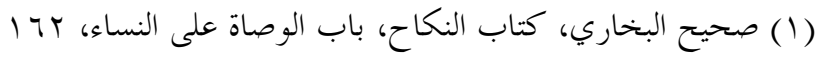

$$
\begin{aligned}
& \text { - } 19 V \text { _ }
\end{aligned}
$$


(1) (1)

وبحفظ الرجل لها تستقر الأسرة، إذ لابد لكل أسرة من رجل يقوم على أمرها؛ لِما

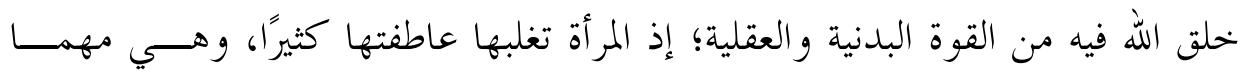
عملت تبقى أضعف من الرجل بدنيًّا. والأصوات القبيحة التي تنادي بإسقاط ولاية الرجل عنها إنما هي تصدر من جاهل

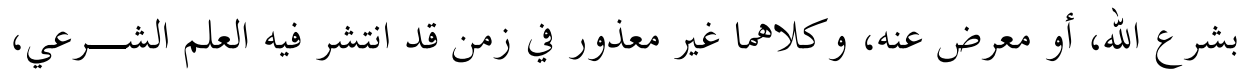
وتيسر الوصول إليه.

وهذه الدعوة إنما تريد حرية الوصول إلى المرأة دون حافظ يحفظها ويقوم عليهــا،

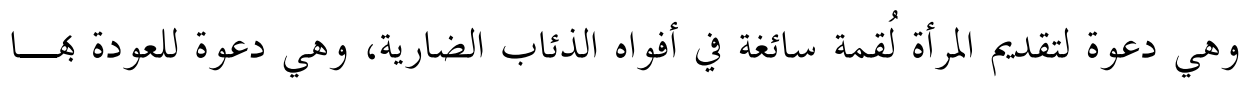
للجاهلية المقيتة التي ظلمت المرأة لسنين طويلة.

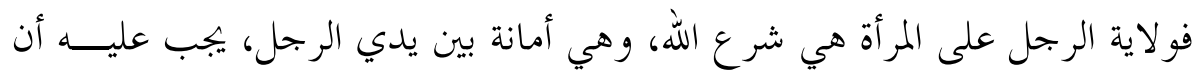

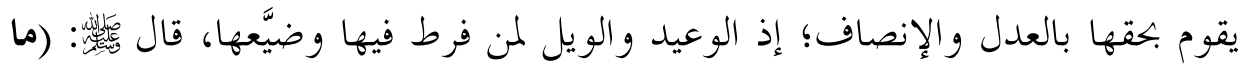

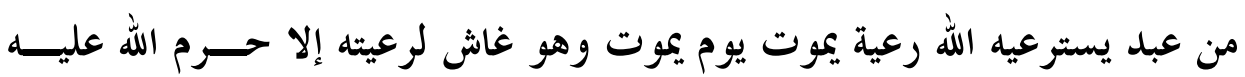
(الجنة) (ب)

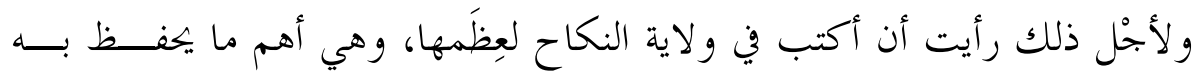
الرجل المرأة حين يتولى عقد اقتراها برجل آخر تنتقل إليه ولاية حفظها والقيام عليها. وقد جعلتُ بحثي في مقدمة، وفصلين، وخاتمة، وهو كالتالي:

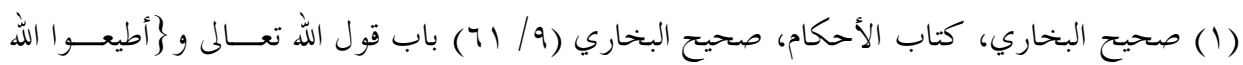

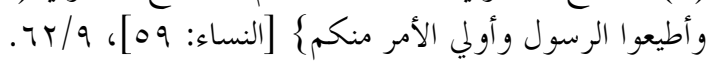

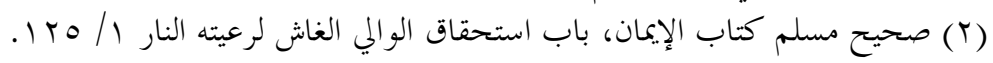


- المقدمة.

- الفصل الأول: الولاية وأقسامها. المبحث الأول: تعريف الولاية لغة واصطلاحًا.

المبحث الثالي: أقسام الولاية. المبحث الثالث: شروط الوليّ. - الفصل الثالي: النكاح بلا وليّ. المبحث الأول: أقوال الفقهاء في النكاح بلا وليّ. المبحث الثاني: أدلة كل فريق. المبحث الثالث: المناقشة والترجيح. - الخاتمة.

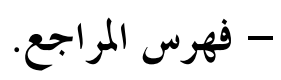

هذا و الله أسأل أن يوفقين فيه وأن يجعله نافعًا لجميع المسلمين. 


\section{الفصل الأول \\ تعريف الولايت وأقسامها}

المبحث الأول: تعريف الولاية لغة واصطلاحًا

\section{تعريف الولاية لغة:}

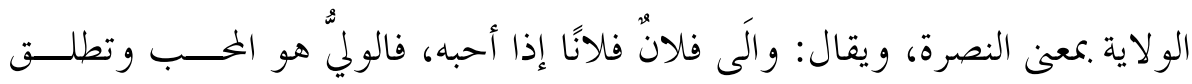

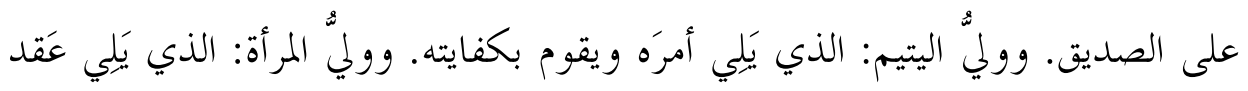

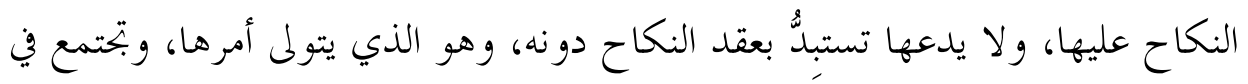

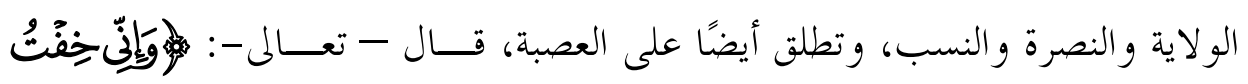

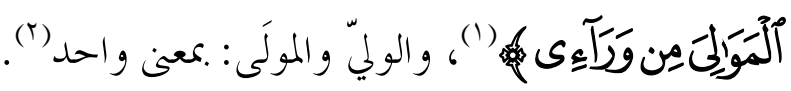

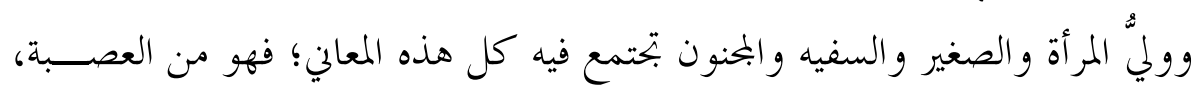

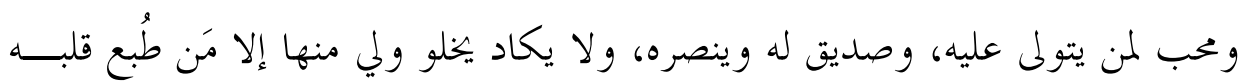

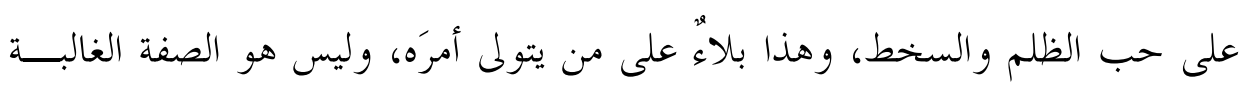

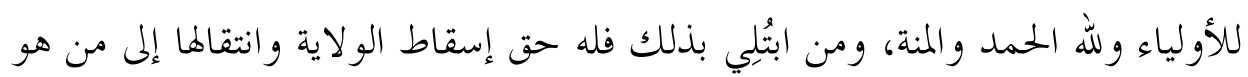
أرأف به ويقوم على مصالحه. الولاية في الاصطلاح:

هي سلطة شرعية يتمكن بها صاحبُها من إدارة شؤون المولَّى عليه، كلِّها أو بعضِها 
وتنفيذها(') فقوله: (سلطة شرعية) أخرجت السلطة غير الشرعية كالمغتصب، وقوله:

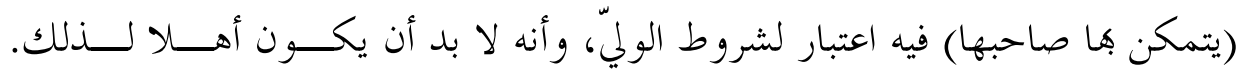
وقوله: (من إدارة شؤون المولى عليه كلها) قد يكون عمل الولي يشمل جميع تصرفات

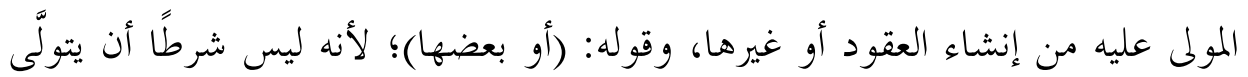

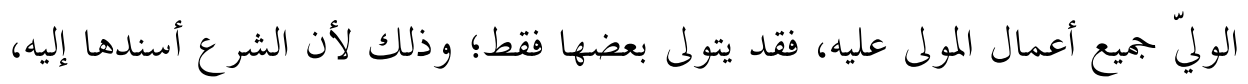

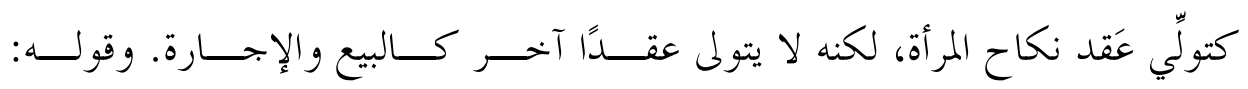
(وتنفيذها)، وهذه نتيجة الولاية في نفاذ تصرف الولي. المبحث الثالي: أقسام الولاية في النكاح الولاية نوعان: ولاية إجبار، وولاية اختيار، وللحنفية تسمية أخرى، وهي: ولايسـة حتم، وولاية ندب و استحباب أو شركة(؟). أما في ولاية الإجبار فاتفق الفقهاء جميعُهم على أن للأب تزويجُ ابنته الصغيرة البكر

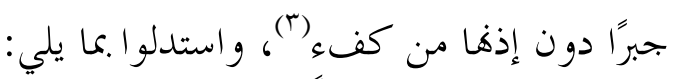

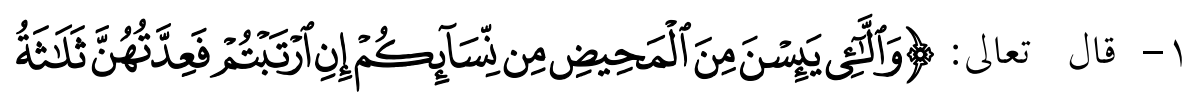

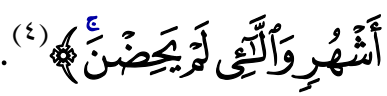
وجه الدلالة: جعل للائي لم يحضن عدة ثلاثة أشهر، ولا تكون العدة ثلاثة أشـــهر (1) بنظر : (1) بلاية التأديب الخاصة في الفقه الإسلامي، د. ابراهيم التنم.

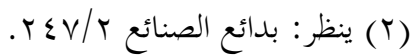

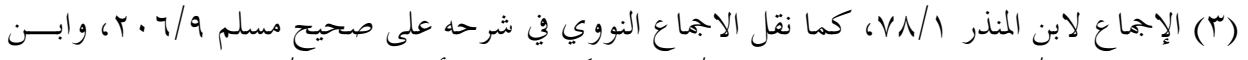

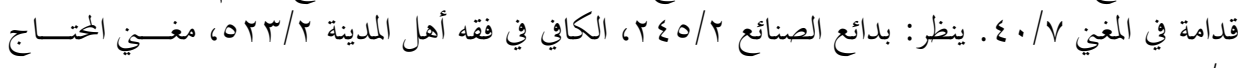
. r $\tau\rceil / \varepsilon$ (ع) سورة الطلاق: ع. ع.

$$
-r \cdot 1-
$$




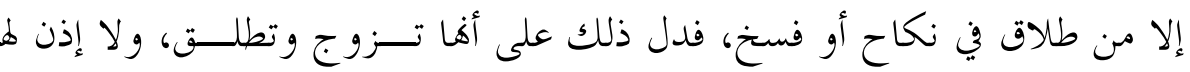
فيعتبر (1)

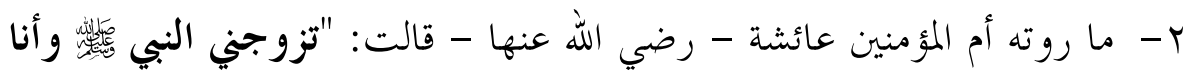

بنت ست سنين، وبنى بي وأنا بنت تسع سنين" (†).

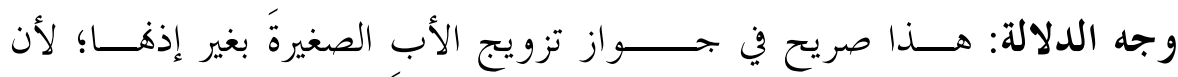

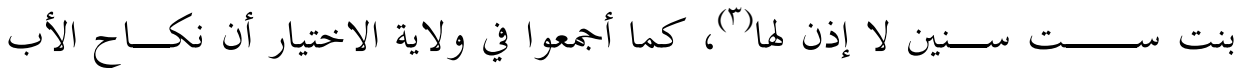

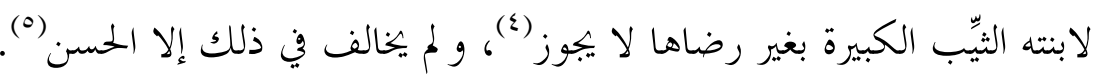

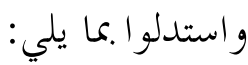

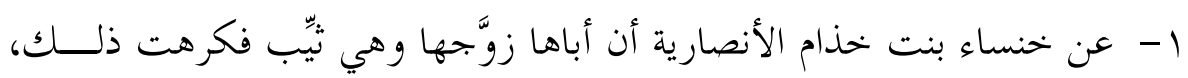

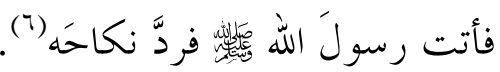

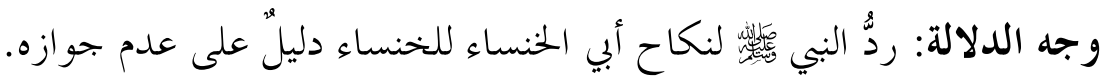

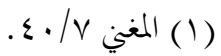

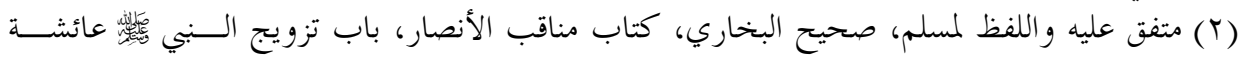

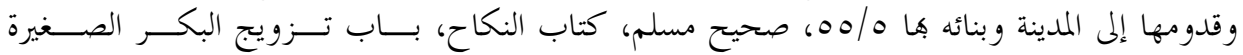

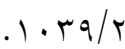

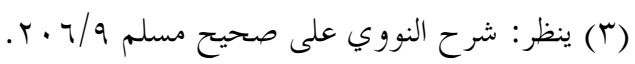

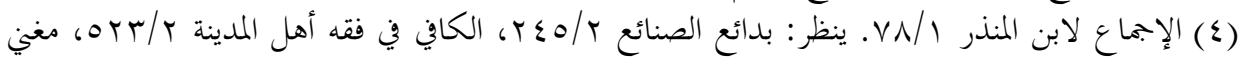

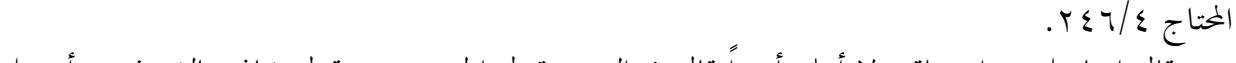
(0) قال إسماعيل بن إسحاق: لا أعلم أحداً قال في البنت بقول الحسن وهو قول شاذ خالف فيــه أهــل

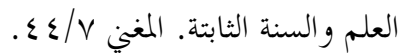

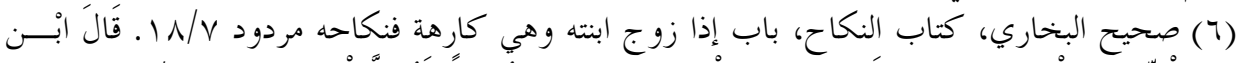

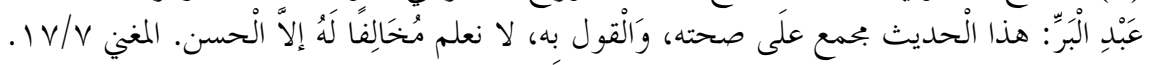

$$
-r_{-} \cdot r_{-}
$$




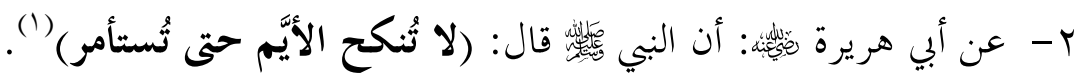

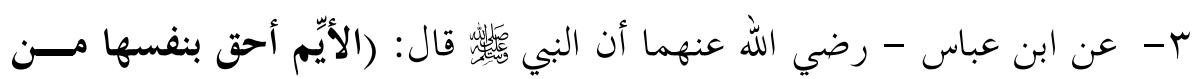

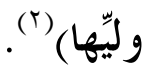

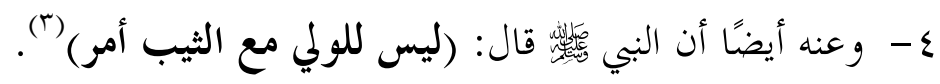
وجه الدلالة من الأحاديث: فيه دلالة واضحة أنه ليس للولي تزويجُ موليته الثيب إلا برضاها و أمرها. واختلف الفقهاء في البكر البالغة والثيب الصغيرة: هل الولاية عليهن ولايةٌ إجبار أم اختيار؟ أما البكر البالغة، فذهب المالكية و الشافعية والحنابلة إلى أن للأبب تزويجَ ابنته البكر البالغة بغير إذها، ويستحب له أن يستأمرها وليس بو اجب عليه (\&). أما الحنفية ورواية للحنابلة فذهبوا إلى أن ولاية الإجبار لا تثبت على البالغة العاقلة،

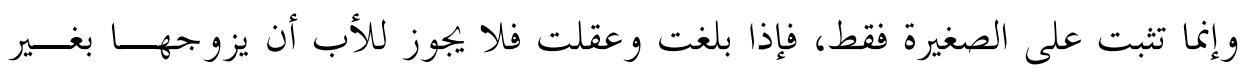
إذها، و لا يجبرها على ذلك (ن)

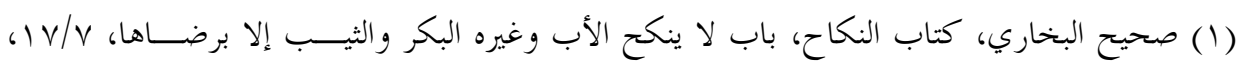

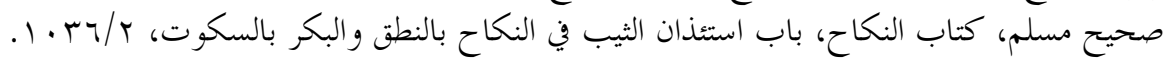

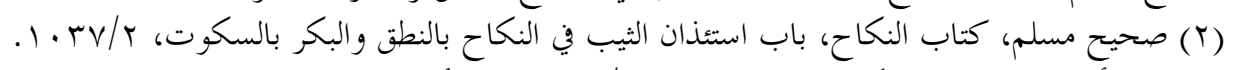

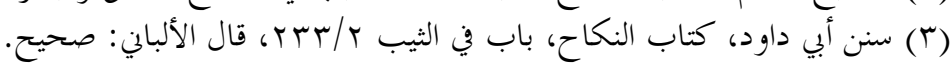

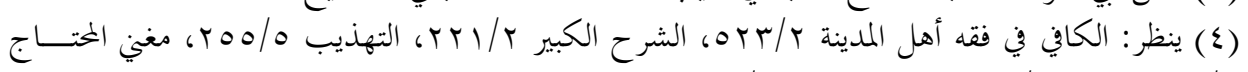

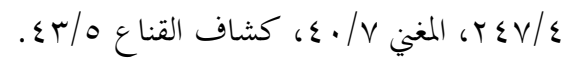

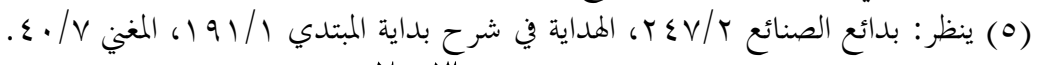
- r. 


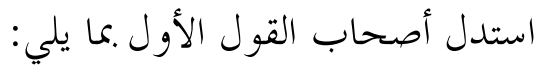

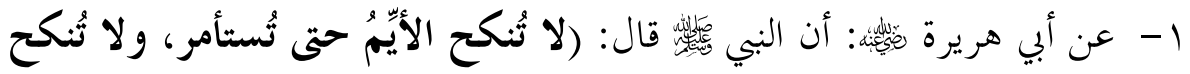

البكرُ حتى ثُستأذن، قالو ا: يا رسول الله، وكيف إذئها، قال: أن تسكت) (').

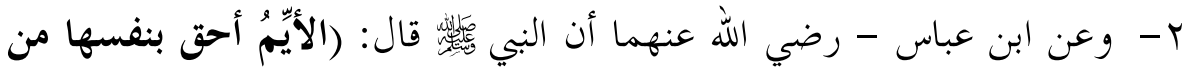

وليها، والبكر ثُستأذن في نفسها، وإذئها صماقا) (ب).

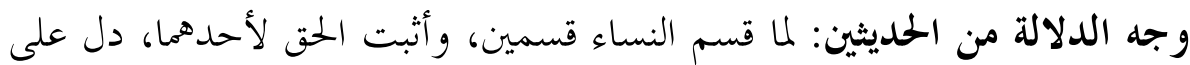

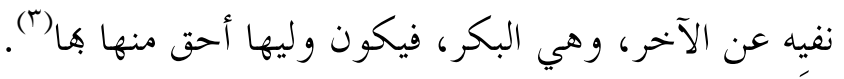

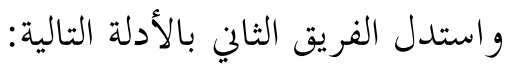

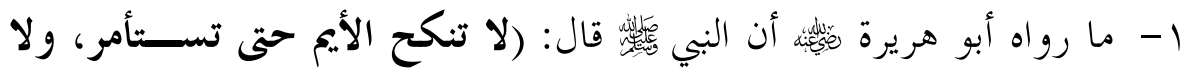

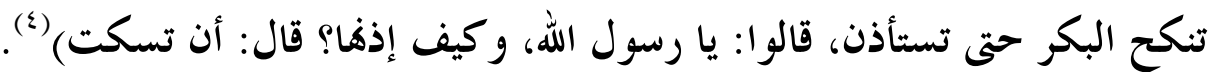

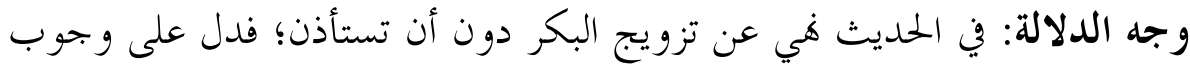

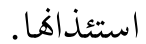

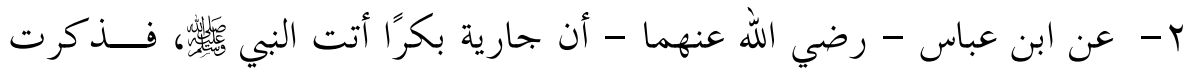

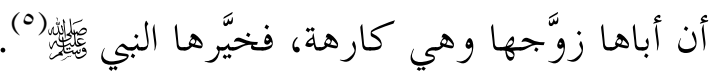

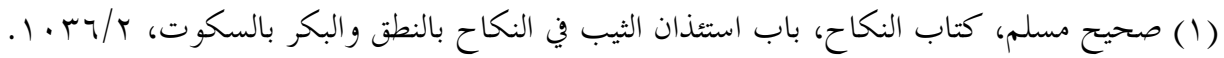

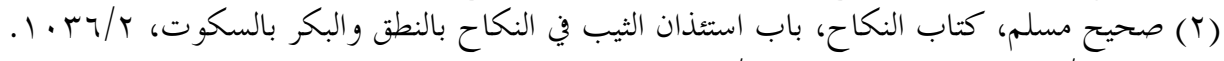

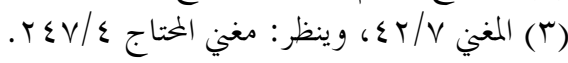

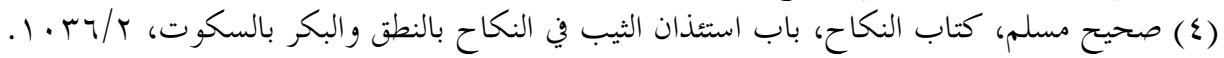

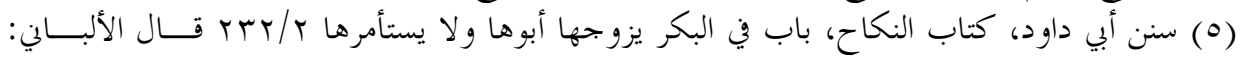


وجه الدلالة: تخيير البي

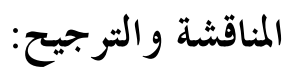
قوله بل

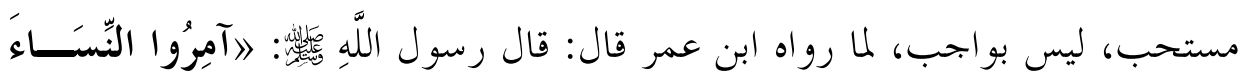

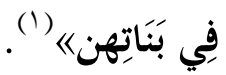

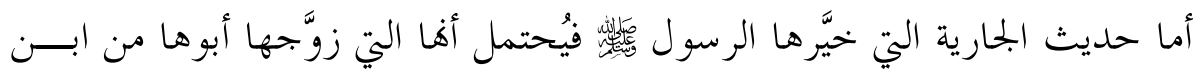

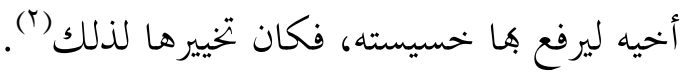
الترجيح: على الرغم من مناقشة أدلة الفريق الثاني فإن المناقشة لم تبطل النهي الذي جـــاء في

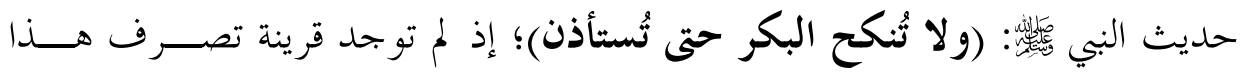

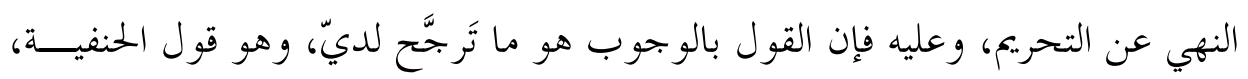
ورواية للحنابلة. و الله تعالى أعلم.

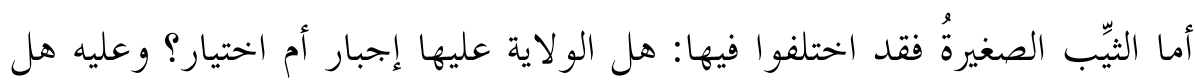

$$
\begin{aligned}
& \text { للأب تزويجها دون إذها أم لا؟ } \\
& \text { وفي هذه المسألة قولان: }
\end{aligned}
$$

الأول: ذهب إلى أن للأب تزويجها دون إذها، فالولاية عليها ولايةٌ إجبار، وهـــــ

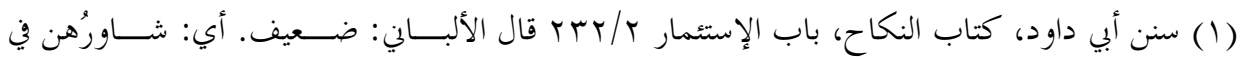

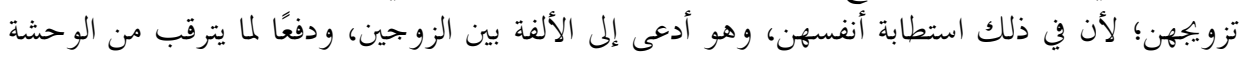

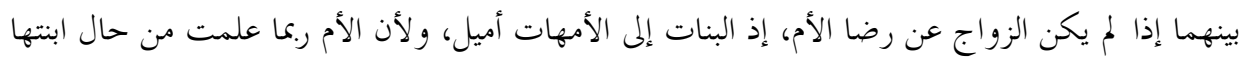

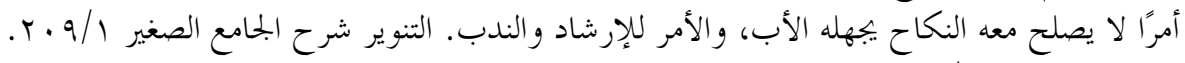
- Y.O. 


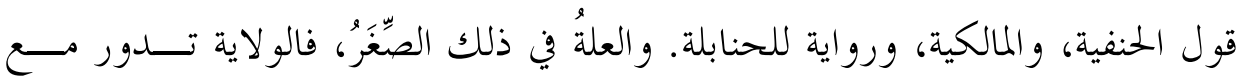

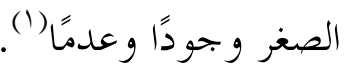

الثاني: ذهب إلى عدم تزويج الثيب الصغيرة؛ لأنه لابد من إذن الثيب، والصغيرةُ لا لا إذن لما معتبر، فلا تُزوَّج حتى تبلغ.

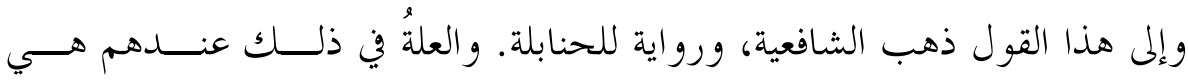
البكارة والثيوبة، فلا تكون ولاية الإجبار إلا للبكر، وهذه ثيب (ج).

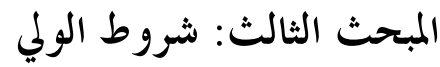
قبل ذكر شروط الولي لابد من معرفة من هو ولي المرأة:

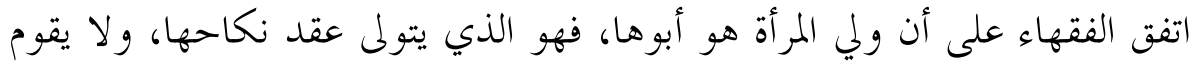

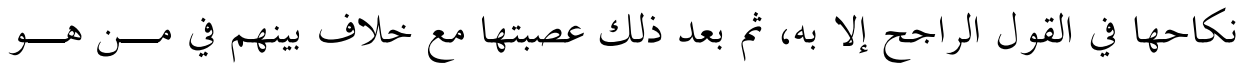

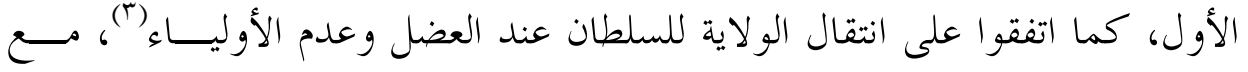

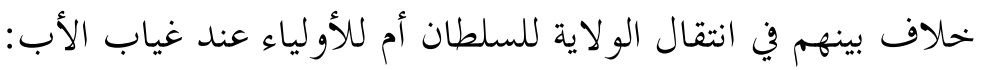

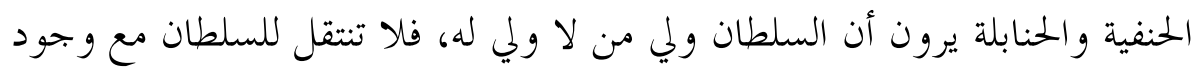
الأولياء() ، أما المالكية والشافعية فيرون بولاية السلطان عند غياب الأب، إلا إذا كان الأب الغائب قد انقطع خبره فيزوجها الأولياء (م).

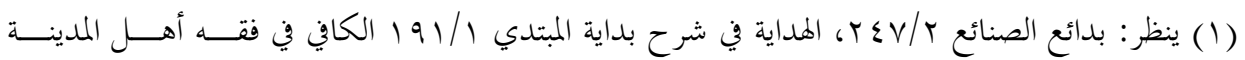
إن

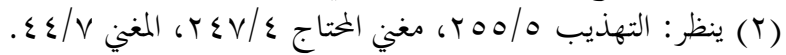

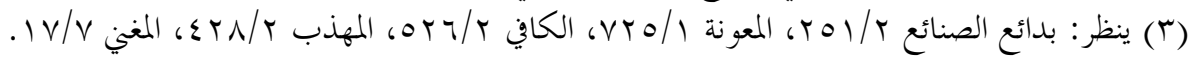

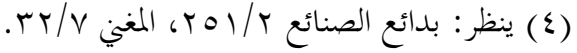

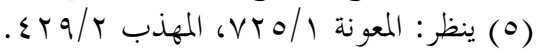


يشترط في الولي العاقد للنكاح شروط ستة: الأول: الإسلام ؛ إذ لا ولاية لكـــافر،

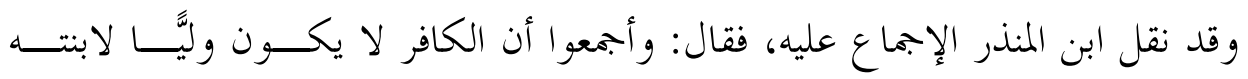

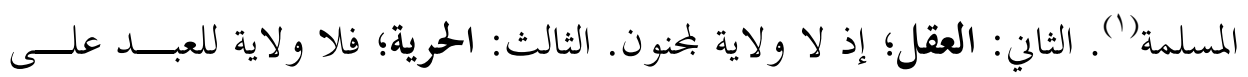
الحرة. الرابع: الذكورية؛ لأن المرأة يولى عليها لقصورها عن النظر لنفسها. الخـــامس:

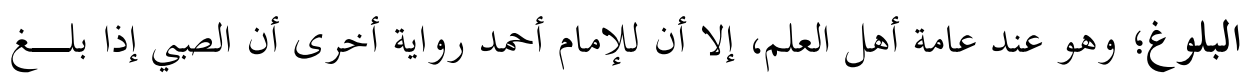

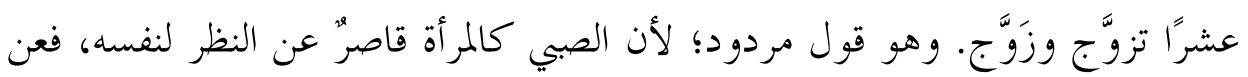

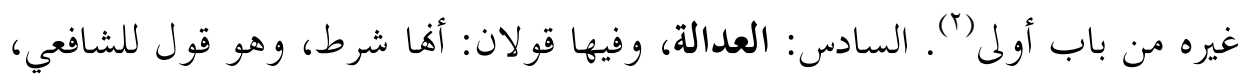

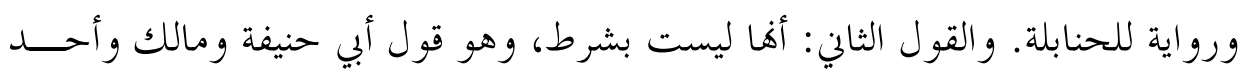
قولي الشافعي ورواية للحنابلة(؟). 


\section{الفصل الثاني \\ النسكاح بلا ولي الني}

\section{المبحث الأول: أقوال الفقهاء في النكاح بلا ولي}

اختلف الفقهاء في الولاية في عقد النكاح: هل هي شرط في صحة النكـــــ أو لا؟

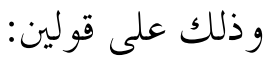

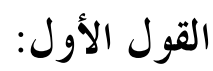
ذهب أصحابه إلى أن الولاية شرط في صحة النكاح، و لا يصح نكاح المرأة بـــدون ولي، وليس لها تزويج نفسها، ولا تو كيل غير وليها في نكاحها، و النكاح بذلك يكون

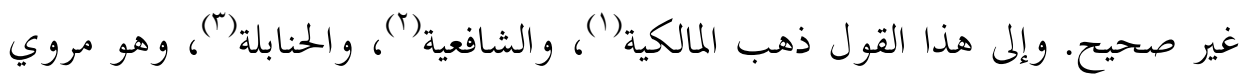
عن عمر بن الخطاب، وعلي بن أبي طالب، وابن مسعود، وابن عباس، وأبي هريــرة،

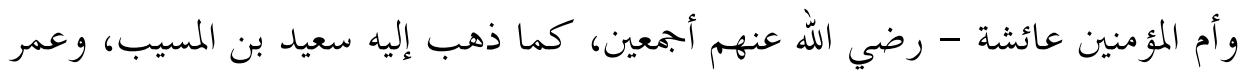
بن عبد العزيز، و ابن المبارك، و الثوري، وابن أبي ليلى، وغيرهم (ع).

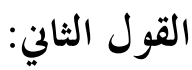
وهو ما ذهب إليه الحنفية(ْ) وقد تفرقت أقوالهم: فأبو حنيفة وأبو يوسف في ظاهر

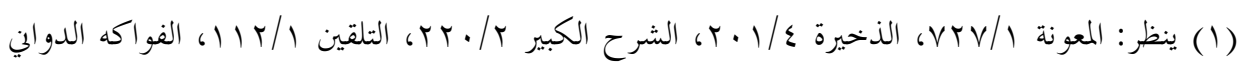
. $2 / Y$

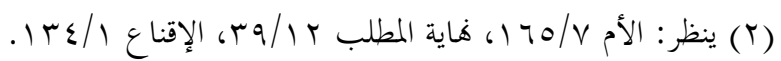

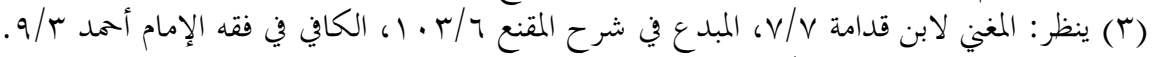

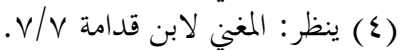

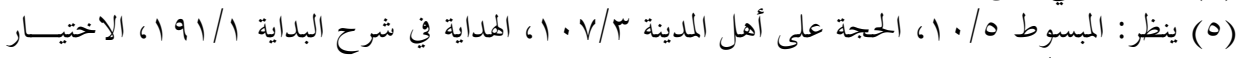

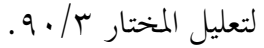




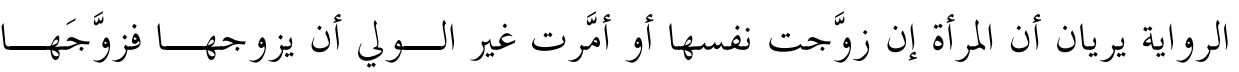

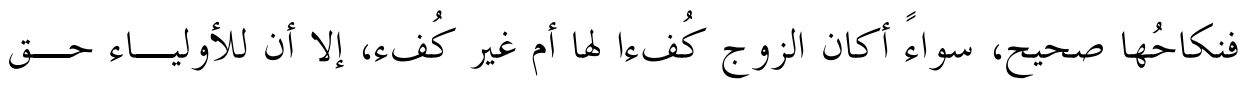
الاعتر اض إن كان ليس بكفء.

وروي عن أبي يوسف أيضًا أنه لا ينعقد إلا بولي، وروى الطحاوي عن أبي يوسف

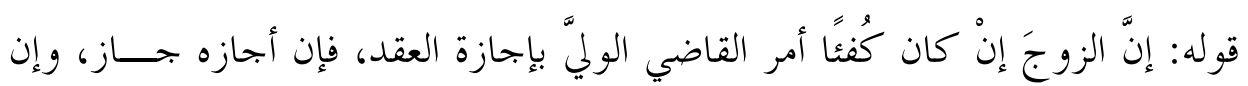
أبى أن يجيزه لم ينفسخ، ولكن القاضي يجيزه فيجوز إن.

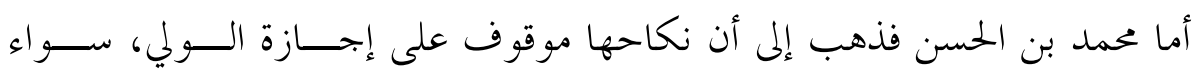

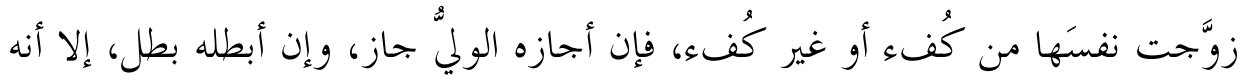

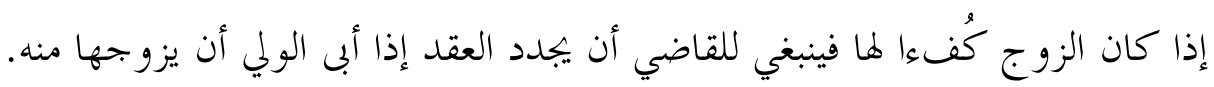

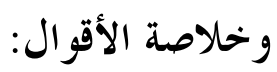

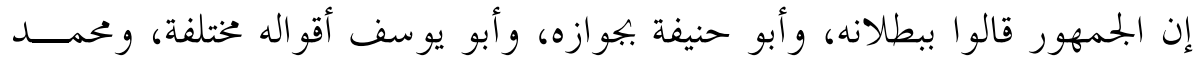
ذهب إلى صحته إن أجازه الولي.

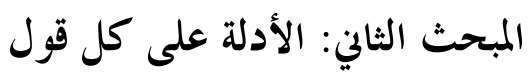

لقد استدل كل فريق بأدلة تقوي مذهبه وتعضده؛ فقد استدل الفريق الأول، وهم المالكية، و الشافعية، و الحنابلة بأدلة من الكتاب و السنة و المعقول، و بياها كالتالي:

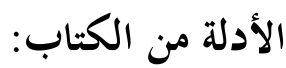

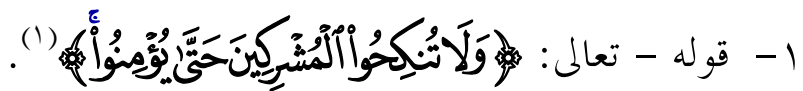

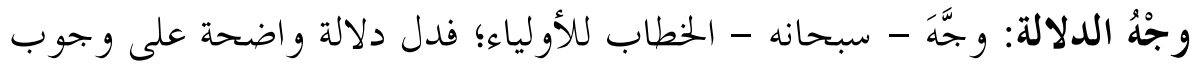


تولي الولي للنكاح، ولو كان نكاح المرأة لنفسها جائزًا لَوجَّه الخطابَ لها مباشرة.

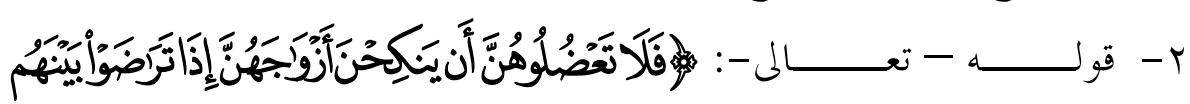

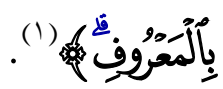
وجه الدلالة: الخطاب في قوله: (فلا تعضلوهن) للأولياء؛ إذ إذها نــــلت في معقل

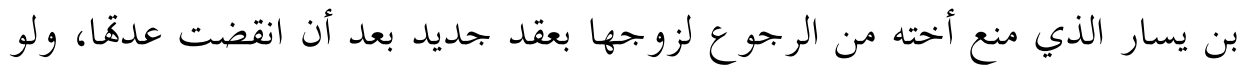

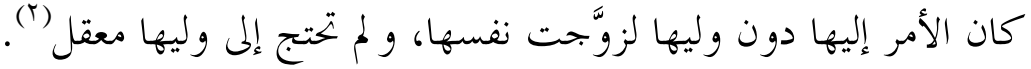

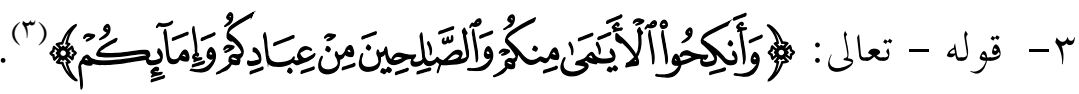

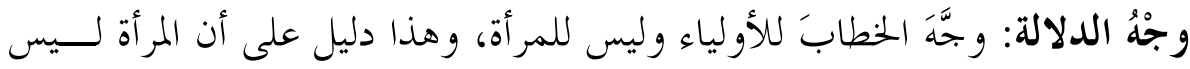

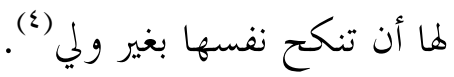

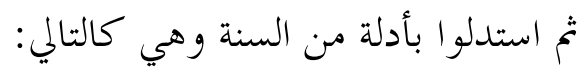

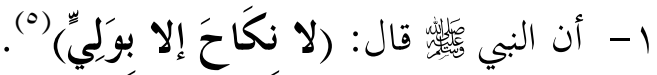

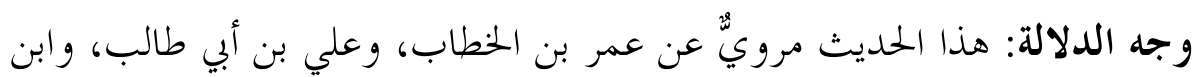

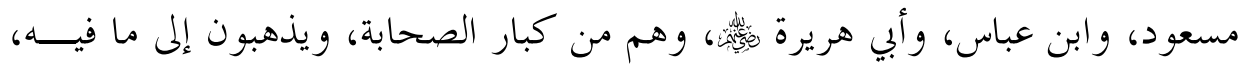
وفيه دلالة واضحة على عدم جواز النكاح بدون ولي. 
r- عن عائشة - رضي الله عنها - قالت: قال رسول الله بغير إذن مو اليها فنكاحها باطل - ثلاث مرات - فإن دخل بها فالمهر لها بما أصاب

\section{منها، فإن تشاجروا فالسلطان ولي من لا ولي له) (1).}

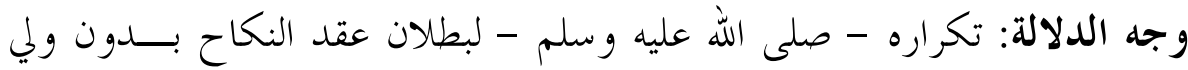
يدل دلالة واضحة على فساده وعدم جوازه.

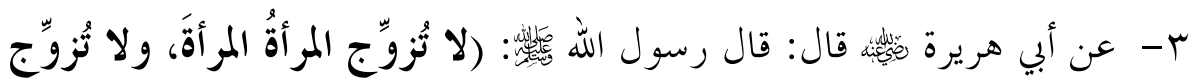

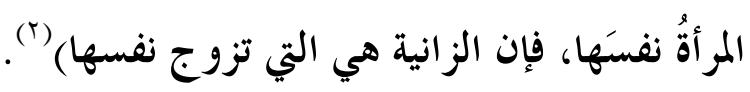

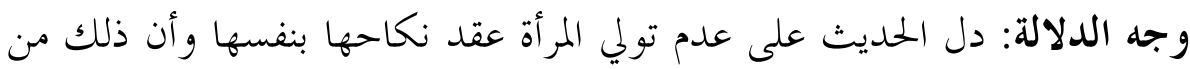
شأن الزانية؛ فلا ينبغي أن تتحقق المباشرة في النكاح الشرعي (ب).

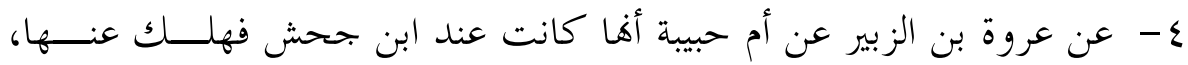

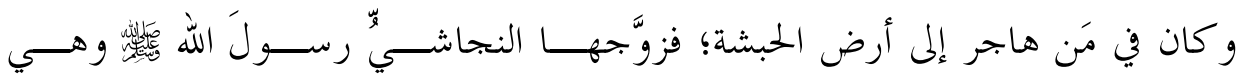

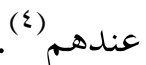

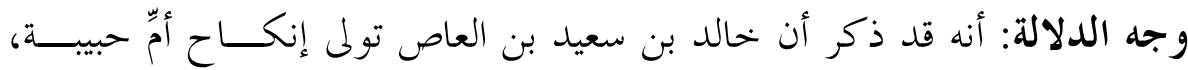
و النجاشيُّ تو كل عن البي

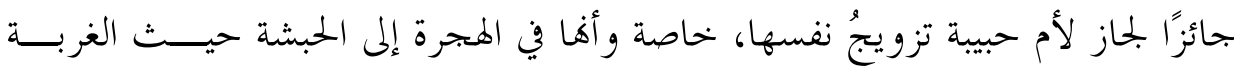

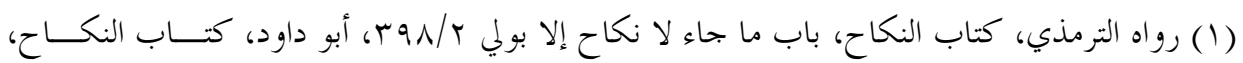

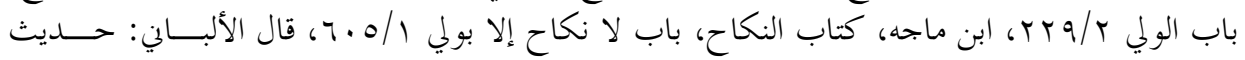

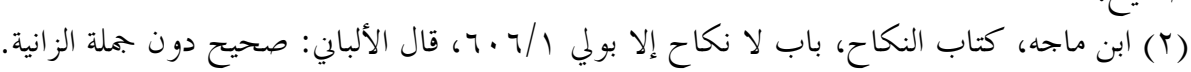

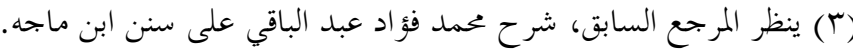

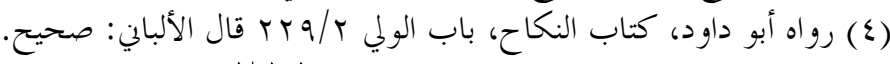


أما استدلالهم من المعقول فقالوا: إن المرأة غير مأمونة على البضع لــنقص عقلــــا

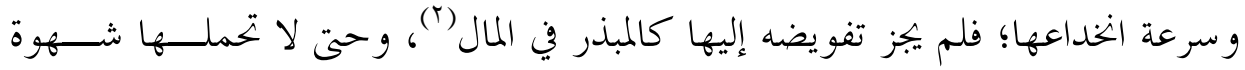
النكاح وميلها إلى الرجال على التسرع في وضع نفسها في غير كفء (r)"، فتلحق عارًا

\section{بأوليائها (๕)}

أدلة الفريق الثاني وهم الحنفية:

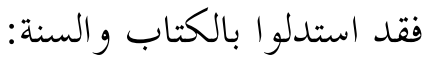

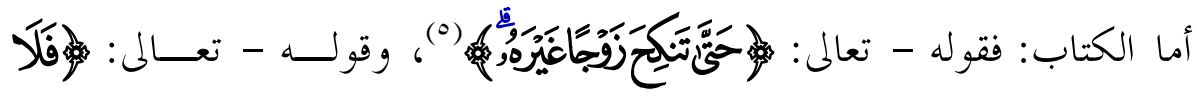

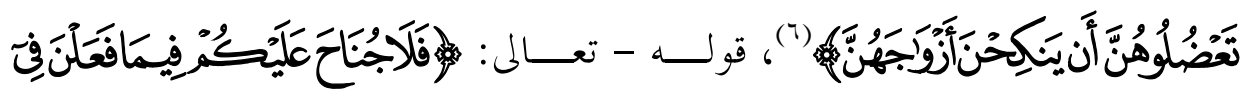

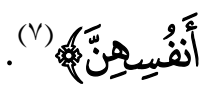

وجه الدلالة: الآيات تصرح بأن النكاح ينعقد بعبارة النساء؛ إذ إنه - سبحانه -

أضاف العقد إليهن في هذه الآيات؛ فدل على أها تملك مباشرة العقد بنفسها(^).

$$
\text { Vo/7 أنظر : (1) }
$$

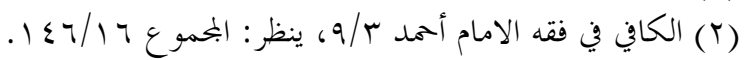

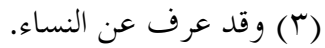

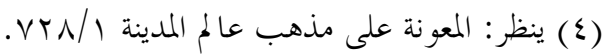

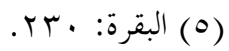

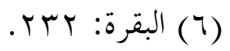

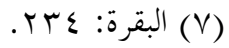

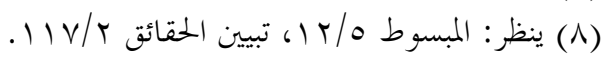


ومن السنة استدلوا بالآتي:

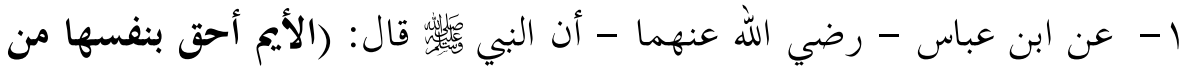

وليها) (1)

وجه الدلالة: فيه دلالة واضحة على أن الحرة البالغة العاقلة لها الولاية على نفسها،

$$
\text { لاسيما أن معنى الأيم هي من لا زوج لها بكرًا كانت أم ثيبًا (r). }
$$

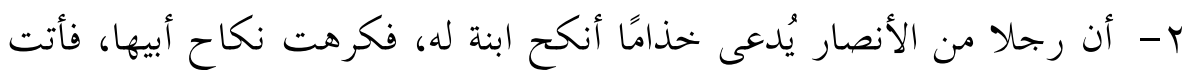

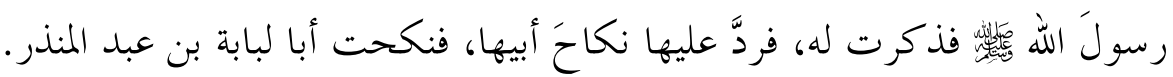

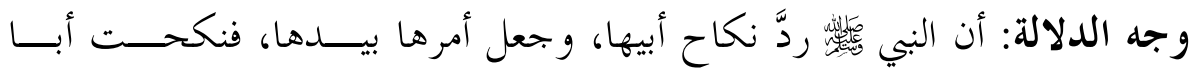

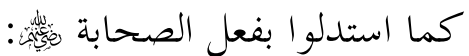

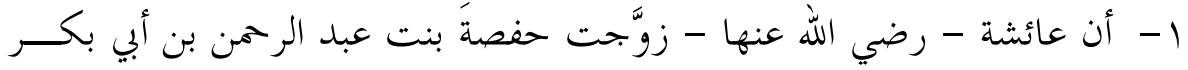

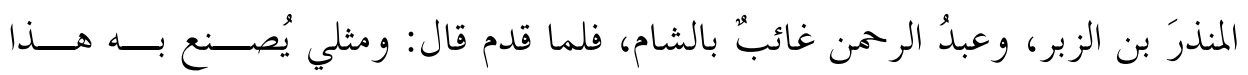

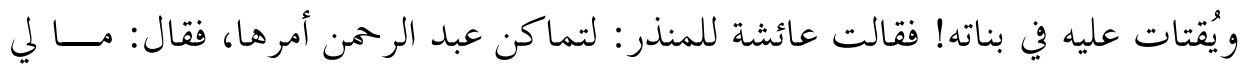
رغبة عنه، ولكن مثلي لا يقتات عليه في بناته (ع).

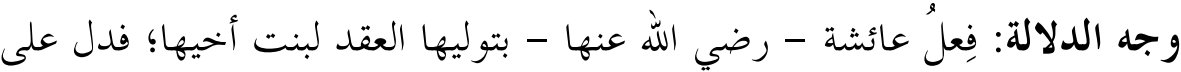
تولي المرأة العقد بنفسها أو عن غيرها.

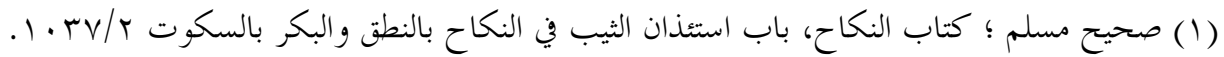

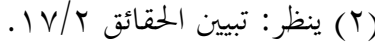

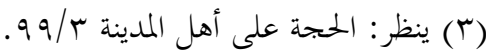

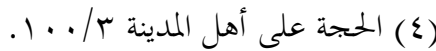


r- عن علي بن أبي طالب نِيلئه أن امرأة زوَّجت ابنتها برضاها، فجاء أولياؤهــــا

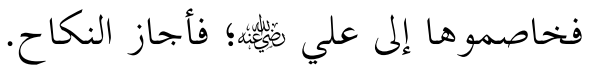
وجه الدلالة: في هذا دليل على أن المرأة إذا زوَّجت نفسَها أو أمرت غير الولي أن

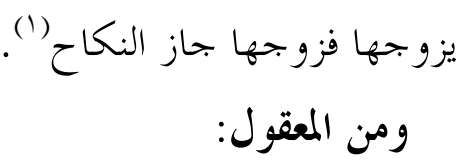
أن المرأة حرة بالغة عاقلة، يجوز لها التصرف في مالها وتعقد عقــود بيــع وشـــــاء وغيرها؛ ففي النكاح الذي هو عقد على بعض منافعها أولى (r). المبحث الثالث: المناقشة والترجيح

ناقش الجمهور أدلة الحنفية بالمناقشة التالية فقالوا:

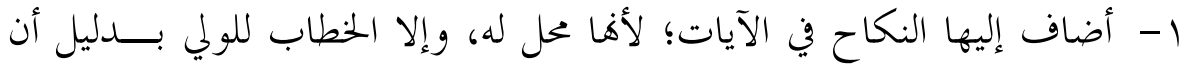

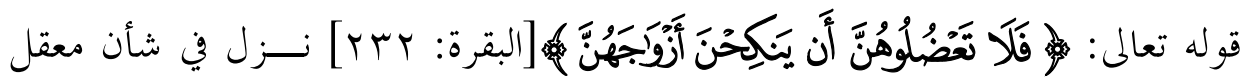

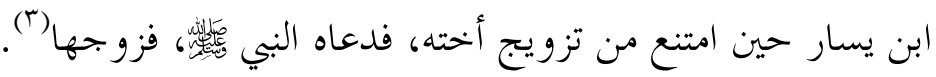

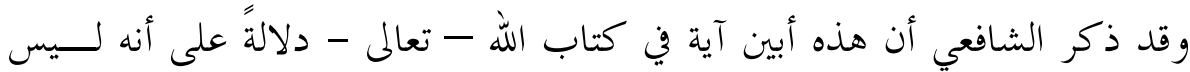

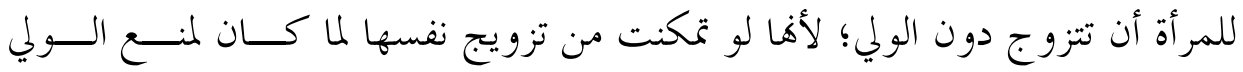
وعضله معنى (\&)

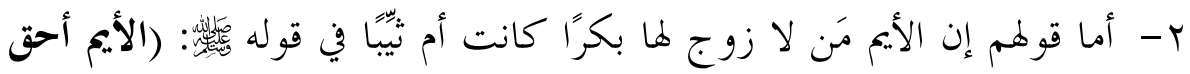

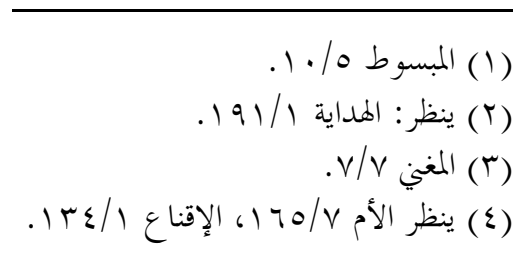


بنفسها) فهذا مردود و إن كان ذلك من إحدى معاني الأيم.

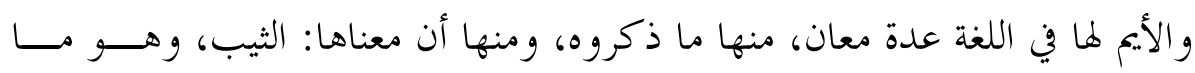

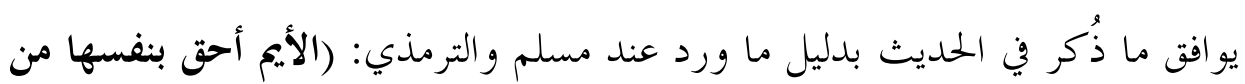

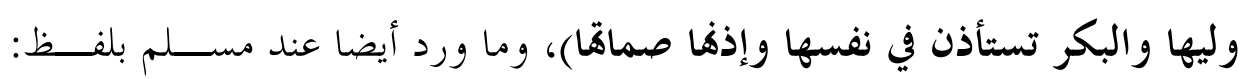

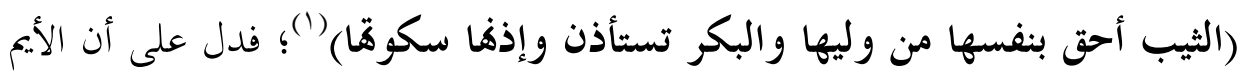

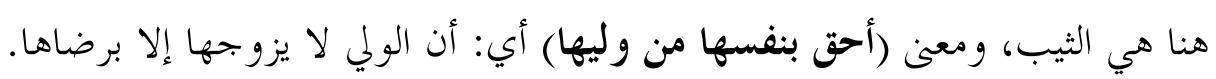

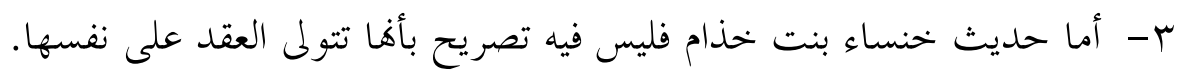

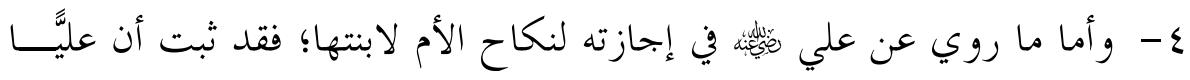

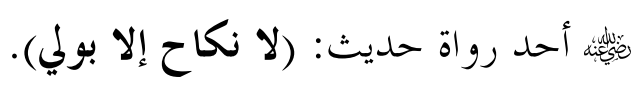

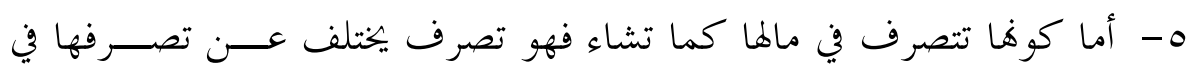

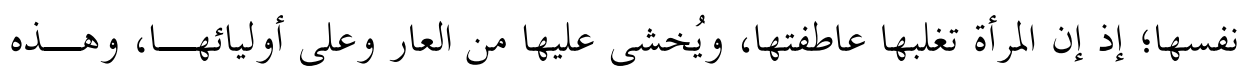

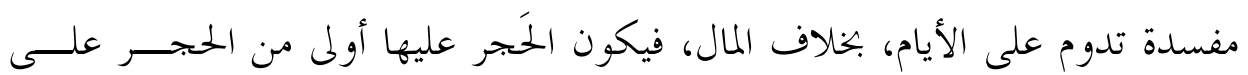

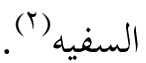
الترجيح:

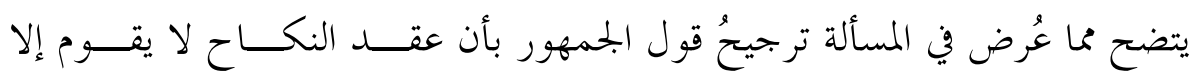

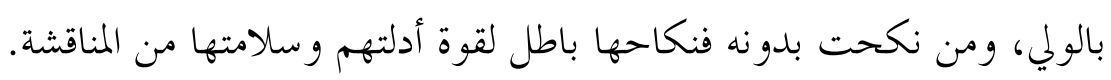
***

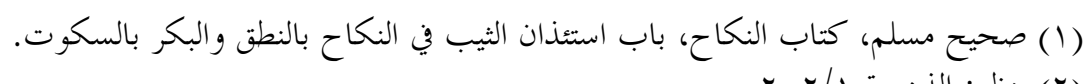

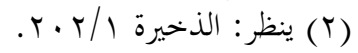
$-Y 10$ 


\section{الخاتهت}

و بعده

فإن محا عُرض سابقًا يتبيَّن أهمية الولي للمرأة في الحفاظ عليها و الاهتمام بشـــؤوها، وهو محا أنعم الله به على المرأة؛ إذ كثير من مصالح المرأة لا تقوم إلا برجل، و الرجــل يميل بشهوته للمرأة، فحتى تتحقق مصالحها لابد من رجل يحافظ عليها لا يشــتهيها، وهذا لا يكون إلا مع الولي المؤدي لما أوجبه الله عليه. و من يتخلى من الأولياء عن الواجب الذي أوجبه الله عليه، إما بإهمال، أو ظلم فإنه يربي المرأة التي تحت يديه على رغبة التخلص من ولاية الرجل عليها؛ إذ لم تر ما يكقق لما الأمان و الحماية. لكن ظلم الولي لها لا يبعل لها الحق في التخلص من الولي والمُضي دون حساب و لا رقيب؛ لأن المرأة كثيرًا ما تُحَكِمٍ هو اها وتثق فيمن لا يستحق ثقتها. وعند ظلم الولي لما لم يجعلها الإسالام دوون حل؛ بل نقل و لايتها لمــن يســتحق أن يكون أهلًا للحفاظ عليها. وعليه أقول: مع كثرة انتشار الدورات التي تصحح المفاهيم، وتصوب الأخطط اء الموجــــودة في البحتمع لابد من تبني دورات تأصيلية علمية تُبيّن دور الرجل في حياة المـــــأة وأهميتــه، وبيان الواجبات القائمة عليه وعليها، والحقوق المراد تأديتها، لا سيما في هذا العصــر الذي سُمِح فيه للأصوات النشاز أن تقول ما يُملي عليها شياطينها. 
ولعل الأقسام الشرعية تساهم في ذلك، حتى يُز ال اللبس عن بعض المفاهيم الخاطئة، و التي قد نشأ بعضها من بعض موروثات الجاهلية الباطلة.

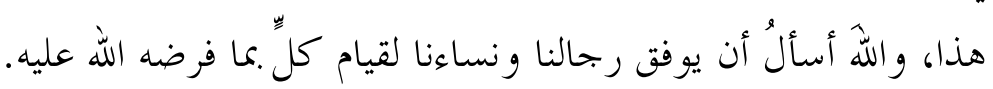
*** 


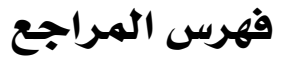

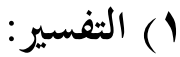

الجحامع لأحكام القر آن، أبو عبد الله محمد بن أحمد بن أبي بكر بن فرح الأنصاري الخزرجي شمس الدين القرطبي، المتوفى: الهاهــ- تحقيق: أحمد البردوني وإبراهيم

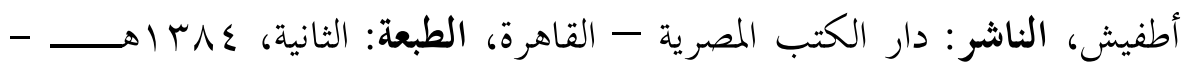
. $197 \varepsilon$

( ) الحديث: (r

صحيح البخاري، الجامع المسند الصحيح المختصر من أمور رسول الله وأيامه، محمد بن إسماعيل أبو عبدالله البخاري الجحفي، الخقق: محمد زهير بن ناصر

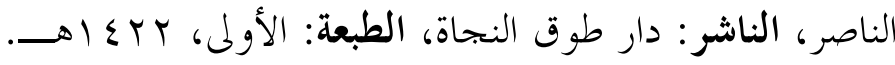
صحيح مسلم، المسند الصحيح المختصر بنقل العدل عن العدل إلى رسول الله ئلئ

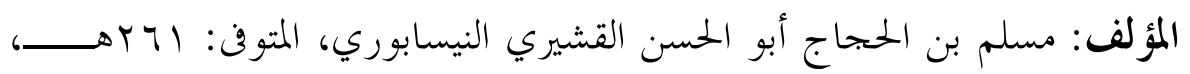
الخقق: محمد فؤاد عبد الباقي الناشر: دار إحياء التراث العربي - بيروت.

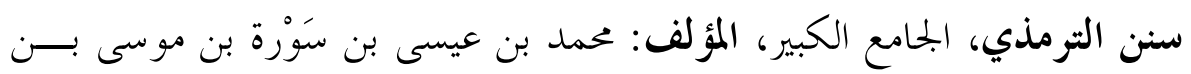

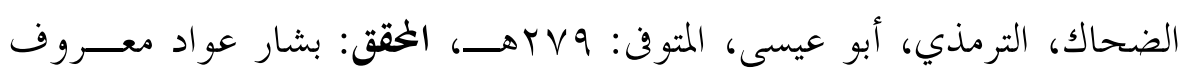
الناشر: دار الغرب الإسلامي - بيروت، سنة النشر 199 أم.

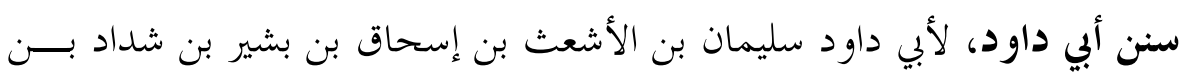

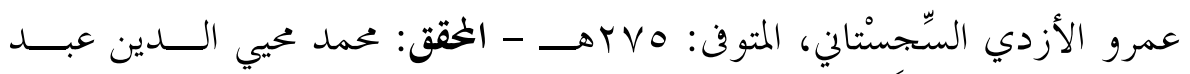


الحميد، الناشر: المكتبة العصرية، صيدا - بيروت.

سنن ابن ماجه، لابن ماجة أبو عبد الله محمد بن يزيد القزويني، و ماجة اسم أبيـــ

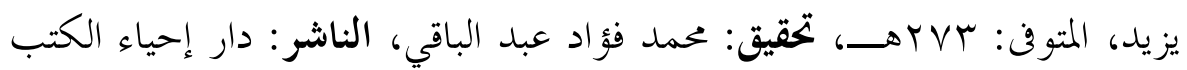
العربية - فيصل عيسى البابي الحلبي. سنن الدار قطني، المؤلف: أبو الحسن علي بن عمر بن أحمد بن مهلدي بن مسعود ابن النعمان بن دينار البغدادي الدار قطين، المتوفى: مبهــ، حققه وضبط نصه وعلق عليه: شعيب الارنؤوط، حسن عبد المنعم شبي، عبد اللطيف حـــرز الله،

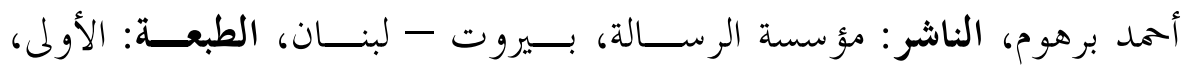

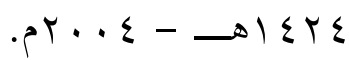
عون المعبود شرح سنن أبي داود، ومعه حاشية ابن القيم: قذذيب ســنـ أبي داود وإيضاح علله و مشكاته المؤلف: محمد أشرف بن أمير بن علي بن حيدر، أبو عبد الرحمن، شرف الحق، الصديقي، العظيم آبادي، المتوف: جوبا اهــ، الناشر: دار الكتب العلمية - بيروت الطبعة: الثانية، 10 التنوير شرح الجامع الصغير، محمد بن إسماعيل بن صلاحح بن محمـــــ الحســـي، الكحلاني ثم الصنعاني، أبو إبراهيم، عز الدين، المعروف كأسلافه بالأمير، المتوفن: r 1 1 اهـــ، الخققق: د. محمَّد إسحاق محمَّد إبراهيم الناشر: مكتبة دار الســلامج،

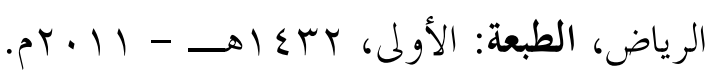
فتح الباري شرح صحيح البخاري، زين الدين عبد الرحمن بن أحمد بن رجـــبـ

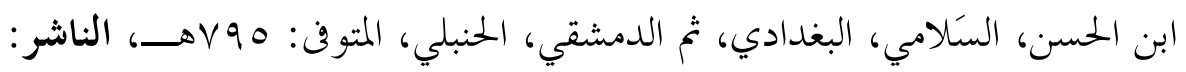


مكتبة الغرباء الأثرية - المدينة النبوية. الحقوق: مكتب تحقيــق دار الحــــين -

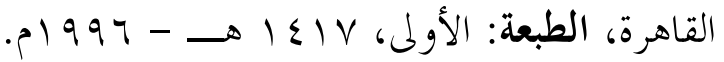

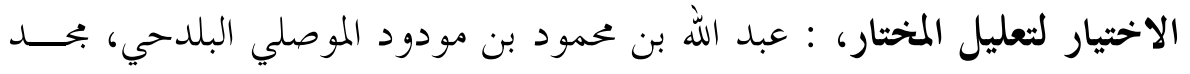

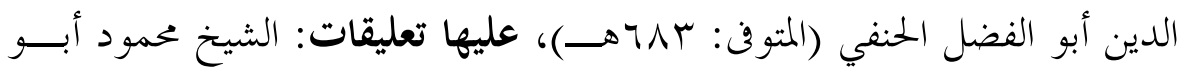
دقيقة (من علماء الحنفية ومدرس بكلية أصول الدين سابقا، الناشر: مطبعة الحلبي

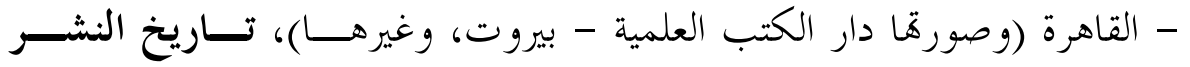

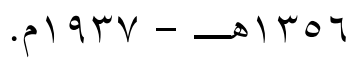
بدائع الصنائع، علاء الدين، أبو بكر بن مسعود بن أحمــد الكاســاني الحنفــي

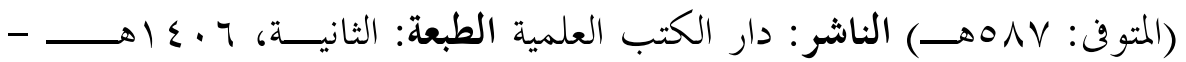
.01917 تبيين الحقائق شرح كنــز الدقائق، عثمان بن علي بن محجن البارعي، فخر الدين

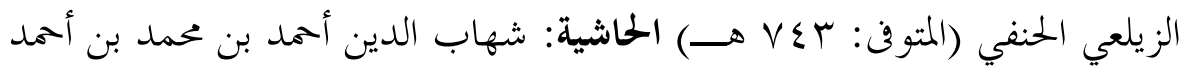

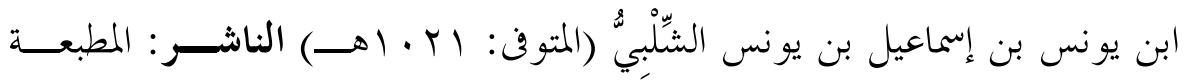

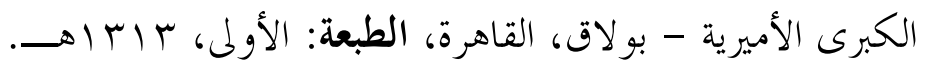
الحجة على أهل المدينة، أبو عبد الله محمد بن الحسن بن فرقد الشيباني (المتــــوفن: 9 111هـ) الخقق: مهدي حسن الكيلاني القادري الناشر: عالم الكتب - بيروت، الطبعة: الثالثة، ب • ـ ا. 
المبسوط، محمد بن أحمد بن أبي سهل شمس الأئمة السرخسي (المتوفى: بیعهــ)

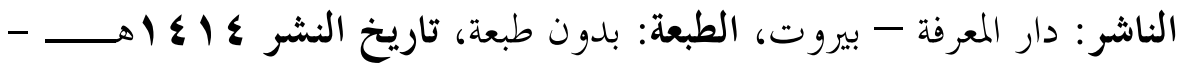
. $199 \mu$ المداية في شرح بداية المبتدي المؤلف: علي بن أبي بكر بن عبد الجليل الفرغــاني

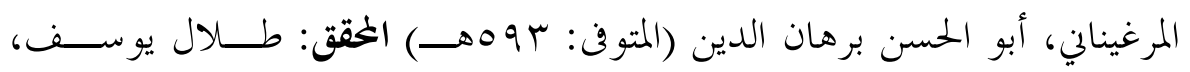
الناشر: دار احياء التراث العربي - بيروت - لبنان.

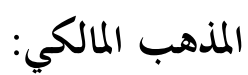
بداية الجنتهد وهاية المقتصد، أبو الوليد محمد بن أحمد بن محمد بن أحمد بن رشد

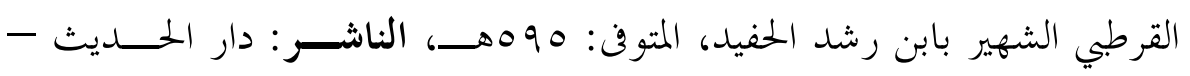

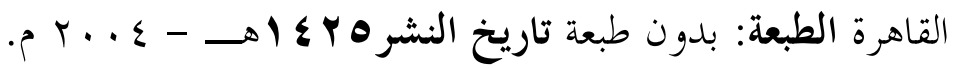
التلقين في الفقه المالكي، أبو محمد عبد الوهاب بن علي بن نصر الثعبي البغدادي

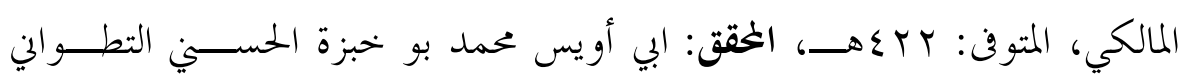

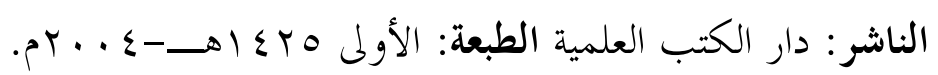
الذخيرة، أبو العباس شهاب الدين أحمد بن إدريس بن عبد الرحمن المالكي الشهير

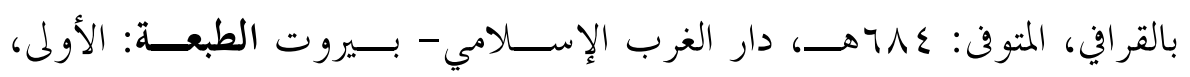
. $199 \varepsilon$ حاشية الدسوقي على الشرح الكبير، محمد بن أحمد بن عرفة الدسوقي المالكي، المتوفى: · ب إهــ، الناشر: دار الفكر الطبعة: بدون طبعة، وبدون تاريخ. الفواكه الدوالي على رسالة ابن أبي زيد القيروالي، أحمد بن غانم (أو غنيم) بــنـ 


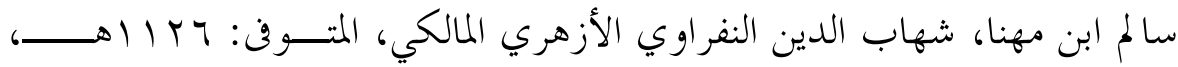
الناشر: دار الفكر الطبعة، بدون طبعة تاريخ النشره إع اهـــ - 1990 أم. الكافي في فقه أهل المدينة، أبو عمر يوسف بن عبد الله بن محمد بن عبد البر بــنـ

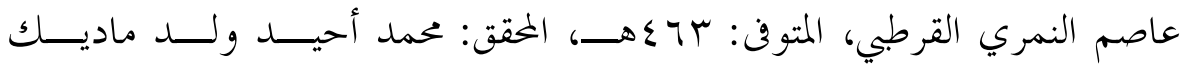
الموريتاني الناشر: مكتبة الرياض الحلديثة، الرياض، المملكــــة العربيـــة الســعودية،

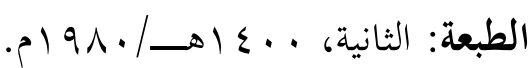
المعونة على مذهب عالم المدينة "الإمام مالك بن أنس"، أبو محمد عبد الوهـــاب

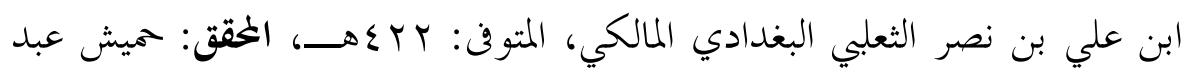
الحقّ الناشر: المكتبة التجارية، مصطفى أحمد الباز - مكة الملكرمة، أصل الكتاب: رسالة دكتوراه بجامعة أم القرى .بمكة المكرمة الطبعة: بدون.

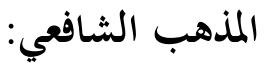
الأم، الشافعي أبو عبد الله محمد بن إدريس بن العباس بن عثمان بن شافع بن عبد المبد المطلب بن عبد مناف المطلبي القرشي المكي المتوفى: ع • بهـــ، الناشر: دار المعرفة

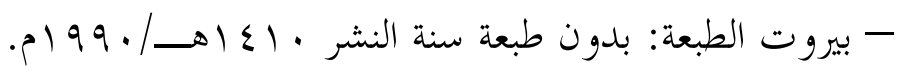
الإقناع في الفقه الشافعي أبو الحسن علي بن محمد بن محمد بن حبيب البصــري

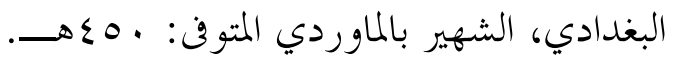
التهذيب في فقه الإمام الشافعي، محيي السنة، أبو محمد الحسين بن مسعود بــنـ

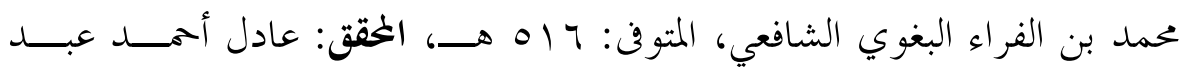

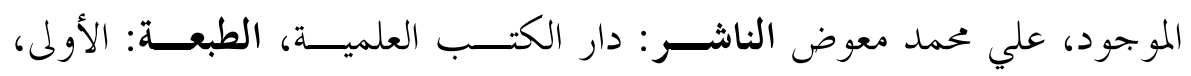




$$
.2199 V-\rightarrow 1 \leqslant 11
$$

الجموع شرح المهذب (مع تكملة السبكي والمطيعي) أبو زكريا ميي الدين بيى ابن شرف النووي، المتوف: 7V7هـــ، الناشر: دار الفكر. مغني الغختاج إلى معرفة معالن ألفاظ المنهاج، المؤلف: شمس الدين، محمد بن أحمد الخطيب الشربيني الشافعي، المتوف: وVVهـــ، الناشر: دار الكتب العلمية، الطبعة

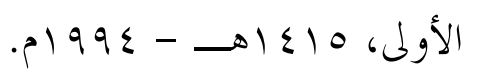

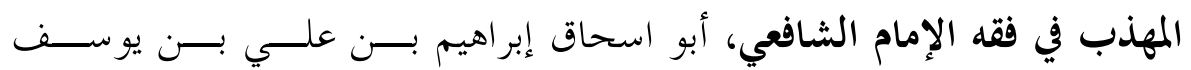
الشيرازي، المتوفى: ج \عهـ، الناشر: دار الكتب العلمية.

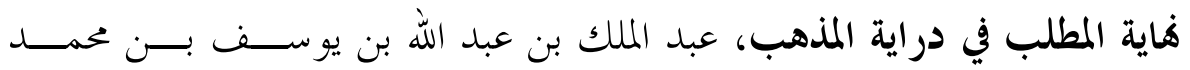

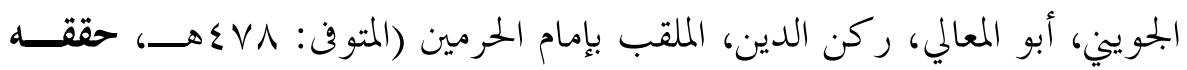
وصنع فهارسه: أ. د/ عبد العظيم محمود الدّيب الناشر: دار المنـــهاج الطبعسة:

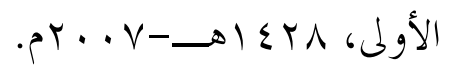

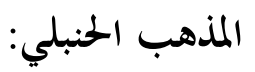

كثاف القناع عن متن الإقناع، المؤلف: منصور بن يونس بن صلاح الدين ابن

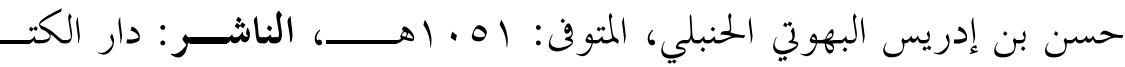
العلمية. الكافي في فقه الإمام أحمد، أبو محمد موفق الدين عبد الله بن أحمد بن حمدد بــن قدامة المقدسي ثم الدمشقي الحنبلي، الشهير بــابن قدامــــة المقدســي، المتــــوف:

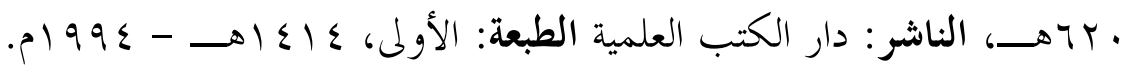


المبدع في شرح المقنع، المؤلف: إبراهيم بن محمد بن عبد الله بن محمد ابن مفلح،

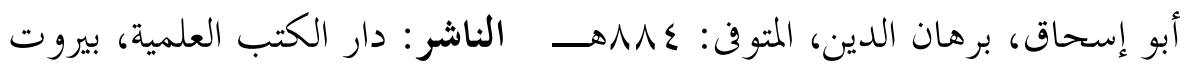

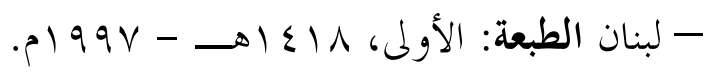

المفني، أبو محمد موفق الدين عبد الله بن أحمد بن محمد بـــن قدامـــة المقدسـي ثئ

الدمشقي الحنبلي، الشهير بابن قدامة المقدسي، المتوفى: · با7هــ، الناشر: مكتبة

$$
\text { القاهرة الطبعة: بدون طبعة. }
$$

ع ) متفرقات:

الإجماع، أبو بكر محمد بن إبراهيم بن المنذر النيسابوري، المتــوفى: 9 آههـــــ

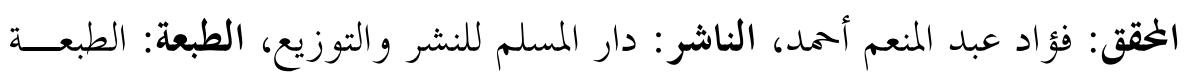

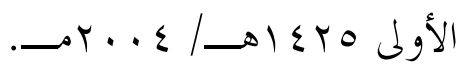

ولاية التأديب الحخاصة في الفقه الإسلامي، د. ابراهيم التنم.

مقالة الولاية على المرأة تشريع أم تضييق؟، د. أميرة علي الصاعدي، موقع صيد

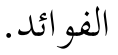

